\title{
Enhanced Fenton degradation of Rhodamine B over nanoscaled Cu-doped $\mathrm{LaTiO}_{3}$ perovskite
}

\author{
Lili Zhang, Yulun Nie*, Chun $\mathrm{Hu}^{*}$, Jiuhui Qu \\ State Key Laboratory of Environmental Aquatic Chemistry, Research Center for Eco-Environmental Sciences, Chinese Academy of Sciences, Beijing 100085, China
}

\section{A R T I C L E I N F O}

\section{Article history:}

Received 18 April 2012

Received in revised form 11 June 2012

Accepted 18 June 2012

Available online 23 June 2012

\section{Keywords:}

$\mathrm{Cu}$-doped $\mathrm{LaTiO}_{3}$ perovskite

Fenton-like

Active radicals

Rhodamine B

\begin{abstract}
A B S T R A C T
Cu-doped $\mathrm{LaTiO}_{3}$ perovskite was prepared with a sol-gel method and characterized by X-ray diffraction and $\mathrm{X}$-ray photoelectron spectroscopy. The introduction of $\mathrm{Cu}$ induced the formation of $\mathrm{LaTiO}_{3}$ perovskite in which titanium existed as $\mathrm{Ti}^{3+}$, resulting in the coexistence of $\mathrm{Ti}^{3+/ 4+}$ and $\mathrm{Cu}^{+/ 2+}$ in the perovskite structure. $\mathrm{LaTi}_{0.4} \mathrm{Cu}_{0.6} \mathrm{O}_{3}$ showed highly Fenton activity and stability for the degradation of $\mathrm{RhB}$ with $\mathrm{H}_{2} \mathrm{O}_{2}$ in the initial $\mathrm{pH}$ range of 4-9. Moreover, the catalyst buffered the solution with the tested initial $\mathrm{pH}$ to around 7 during the adsorption process. The studies of electron spin resonance, the effect of radical scavengers and other experiments verified that $\mathrm{H}_{2} \mathrm{O}_{2}$ was predominately converted into $\bullet \mathrm{OH}$ and $\mathrm{HO}_{2} \bullet / \mathrm{O}_{2} \bullet^{\bullet}$ in $\mathrm{LaTi}_{0.4} \mathrm{Cu}_{0.6} \mathrm{O}_{3}$ suspension. A mechanism of heterogeneous Fenton catalysis was proposed on the basis of the both cycles of $\mathrm{Ti}^{3+} / \mathrm{Ti}^{4+}$ and $\mathrm{Cu}^{+} / \mathrm{Cu}^{2+}$ during the interaction of $\mathrm{LaTi}_{0.4} \mathrm{Cu}_{0.6} \mathrm{O}_{3}$ with $\mathrm{H}_{2} \mathrm{O}_{2}$.
\end{abstract}

(c) 2012 Elsevier B.V. All rights reserved.

\section{Introduction}

Advanced oxidation technologies for wastewater treatment have attracted great attention due to the generation of highly potent chemical species $\left({ }^{\bullet} \mathrm{OH}, \mathrm{O}_{2}{ }^{\bullet-}\right.$, etc.), while hydrogen peroxide is a more desirable oxidant agent. The classic Fenton process (dissolved $\mathrm{Fe}(\mathrm{II})$ and $\mathrm{H}_{2} \mathrm{O}_{2}$ ) [1] is capable of degrading organic pollutants into harmless chemicals such as $\mathrm{CO}_{2}$ and $\mathrm{H}_{2} \mathrm{O}$, but its application is limited by the narrow working $\mathrm{pH}$ range $(<4)[2,3]$, separation and recovery of the iron species specially in industrial wastewater treatment [4]. For these reasons, the development of heterogeneous Fenton systems has received considerable interest and many heterogeneous Fenton-like catalysts have been reported, such as iron oxides [5-8], iron-immobilized zeolites [9], clays $[10,11]$, and carbon materials [12]. Unlike the homogeneous systems, these solid catalysts could be recuperated by means of a simple separation operation and reused in next runs. However, the better catalytic performance is dependent on the presence of ultrasonic and/or UV light irradiation to accelerate the electron transfer at the interface of catalyst and water. Thus, some efforts have been made to develop better heterogeneous Fenton-like catalysts under natural conditions. For example, Na-OL-1 [13] and $\mathrm{BiFeO}_{3}$ [14] have evidenced high catalytic activity in presence of $\mathrm{H}_{2} \mathrm{O}_{2}$ for the removal of refractory dyes.

On the other hand, the use of low-valency transition-metal ions like $\mathrm{Cu}^{+}$and $\mathrm{Ti}^{3+}$ in presence of $\mathrm{H}_{2} \mathrm{O}_{2}$ may extend the scope of the

\footnotetext{
* Corresponding authors. Tel.: +86 10 62849628; fax: +86 1062923541.

E-mail addresses: ylnie@rcees.ac.cn (Y. Nie), huchun@rcees.ac.cn (C. Hu).
}

Fenton reaction. The systems of $\mathrm{Cu}^{+}-\mathrm{H}_{2} \mathrm{O}_{2}[15]$ and $\mathrm{Ti}^{3+}-\mathrm{H}_{2} \mathrm{O}_{2}$ [16] have been found to produce highly potent chemical species, but they require operation under strong acidic conditions to prevent the ion precipitation. If $\mathrm{Cu}^{+}$and $\mathrm{Ti}^{3+}$ exist in the solid catalysts, these drawbacks could be overcome. As we know, perovskite-type catalysts $\left(\mathrm{ABO}_{3}\right)$ have attracted a great interest for the unique structural features [17,18]: (1) the defined structure, which allows the introduction of various metal ions to its structural framework; (2) the cation at both A- and B-site could be substituted by a foreign one without destroying the matrix structure, which allows the controlled alternation of the oxidation state of cations or the creation of oxygen vacancies. This paper intends to investigate the performance of $\mathrm{Cu}$ - and Ti-containing perovskites for wastewater treatment through Fenton-like oxidation.

In this paper, $\mathrm{Cu}$-doped $\mathrm{LaTiO}_{3}$ perovskite was prepared, characterized, and assessed for Fenton catalysis. $\mathrm{LaTi}_{0.4} \mathrm{Cu}_{0.6} \mathrm{O}_{3}$ was found to be highly effective for the degradation of Rhodamine $\mathrm{B}(\mathrm{RhB})$ at wide $\mathrm{pH}$ and exhibited excellent long-term stability in the presence of $\mathrm{H}_{2} \mathrm{O}_{2}$. The possible catalytic mechanism was also discussed.

\section{Experimental}

\subsection{Reagents}

Rhodamine $\mathrm{B}(\mathrm{RhB})$, lanthanum nitrate $\left(\mathrm{La}\left(\mathrm{NO}_{3}\right)_{3} \cdot 6 \mathrm{H}_{2} \mathrm{O}\right)$, copper nitrate trihydrate $\left(\mathrm{Cu}\left(\mathrm{NO}_{3}\right)_{2} \cdot 3 \mathrm{H}_{2} \mathrm{O}\right)$, isopropyl alcohol and $\mathrm{H}_{2} \mathrm{O}_{2}$ $(30 \%, w / w)$ were purchased from Sinopharm Chemical Reagent Co., Ltd. Tetrabutyl titanate and citric acid were obtained from Beijing Chemical. The reagent $t$-butanol was provided by Tianjin Fuchen Company. 5,5-Dimethyl-1-pyrroline-N-oxide (DMPO), 
N,N-diethyl-p-phenylenediamine sulfate (DPD) and horseradish peroxidase (POD) was supplied by Sigma. For the adjustment of $\mathrm{pH}$, a diluted aqueous solution of nitric acid or sodium hydroxide was employed. All chemicals were at least analytical grade. Deionized water was used throughout this study.

\subsection{Catalyst preparation}

$\mathrm{Cu}$-doped $\mathrm{LaTiO}_{3}$ perovskite $\left(\mathrm{LaTi}_{1-x} \mathrm{Cu}_{x} \mathrm{O}_{3}, x=0.0-1.0\right)$ was prepared via a preciously reported sol-gel method [19]. In a typical procedure, a mixed solution of $\mathrm{La}\left(\mathrm{NO}_{3}\right)_{3} \cdot 6 \mathrm{H}_{2} \mathrm{O}$ and $\mathrm{Cu}\left(\mathrm{NO}_{3}\right)_{2} \cdot 3 \mathrm{H}_{2} \mathrm{O}$ was stirred for $1 \mathrm{~h}$ at $0{ }^{\circ} \mathrm{C}$. Thereafter, a tetrabutyl titanate solution in isopropyl alcohol was slowly added. The stoichiometric amount of citric acid was added to form the corresponding metal complexes. After stirring continuously for $2 \mathrm{~h}$, the final solution was heated up to $70^{\circ} \mathrm{C}$ to evaporate water. The gel precursor was dried at $110^{\circ} \mathrm{C}$ for $24 \mathrm{~h}$ and then calcined in air at $700^{\circ} \mathrm{C}$ for $5 \mathrm{~h}$. For the highest catalytic activity, the catalyst $\mathrm{LaTi}_{0.4} \mathrm{Cu}_{0.6} \mathrm{O}_{3}$ was used for all of the experiments unless otherwise specified.

\subsection{Characterization}

The powder X-ray diffraction (XRD) pattern of the catalyst was recorded on a Scintag-XDS-2000 diffractometer with $\mathrm{Cu} \mathrm{K} \alpha$ radiation $(\lambda=1.540598 \AA)$. The generator voltage and tube current used were $40 \mathrm{kV}$ and $40 \mathrm{~mA}$, respectively. The $2 \theta$ ranged from $20^{\circ}$ to $70^{\circ}$. The crystalline size was estimated via the Scherer equation. Nitrogen adsorption/desorption experiment was carried out using a Micromeritics ASAP2000 analyzer (Micromeritics, Norcross, GA).

The X-ray photoelectron spectroscopy (XPS) data were taken on an AXIS-Ultra instrument from Kratos using monochromatic $\mathrm{Al} \mathrm{K \alpha}$ radiation $(225 \mathrm{~W}, 15 \mathrm{~mA}, 15 \mathrm{kV})$ and low-energy electron flooding for charge compensation. To compensate for surface charge effects, the binding energies were calibrated using the C1s hydrocarbon peak at $284.80 \mathrm{eV}$.

Reactive oxygen species were detected by electron spin resonance (ESR) spectroscopy using DMPO as a spin trap agent. The ESR spectra were obtained using a Bruker model ESP 300E electron paramagnetic resonance spectrometer (center field: $3480.00 \mathrm{G}$; microwave frequency: $9.79 \mathrm{GHz}$; and power: $5.05 \mathrm{~mW}$ ).

\subsection{Procedures and analysis}

Unless indicated otherwise, $0.07 \mathrm{~g}$ catalyst powders were dispersed in $50 \mathrm{~mL} \mathrm{RhB}$ solution $\left(8 \mathrm{mg} \mathrm{L}^{-1}\right)$. The solution $\mathrm{pH}$ was not controlled during the catalytic reaction. Prior to the addition of $\mathrm{H}_{2} \mathrm{O}_{2}$, the suspensions were magnetically stirred for about $20 \mathrm{~min}$ to establish the adsorption/desorption equilibrium between the dye and catalyst. Then, a certain amount of $\mathrm{H}_{2} \mathrm{O}_{2}$ was added to the above suspensions under continuous magnetic stirring. At given time intervals, $4 \mathrm{~mL}$ aliquots were collected and immediately centrifuged to remove the catalyst for analysis. The RhB concentration in the supernatant was determined by recording variations at the wavelength of maximum absorption using a Hitachi UV-3010 UV-visible spectrophotometer. The total organic carbon (TOC) of the solution was analyzed by a Phoenix 8000 analyser (TekmarDohrmann, USA).

To test the stability and recyclability of $\mathrm{LaTi}_{0.4} \mathrm{Cu}_{0.6} \mathrm{O}_{3}$, the catalyst was filtered, washed with water, and dried at $70^{\circ} \mathrm{C}$. The catalyst was continued to be used in the second cycle. This process was repeated several times.

$\mathrm{H}_{2} \mathrm{O}_{2}$ concentration was determined using a DPD method described in the literature [20]. The concentrations of La, Ti and $\mathrm{Cu}$ in the solutions after reaction for $2 \mathrm{~h}$ were measured by inductively coupled plasma optical emission spectrometry (ICP-OES) on an Optima 2000 (PerkinElmer, Inc.) instrument.

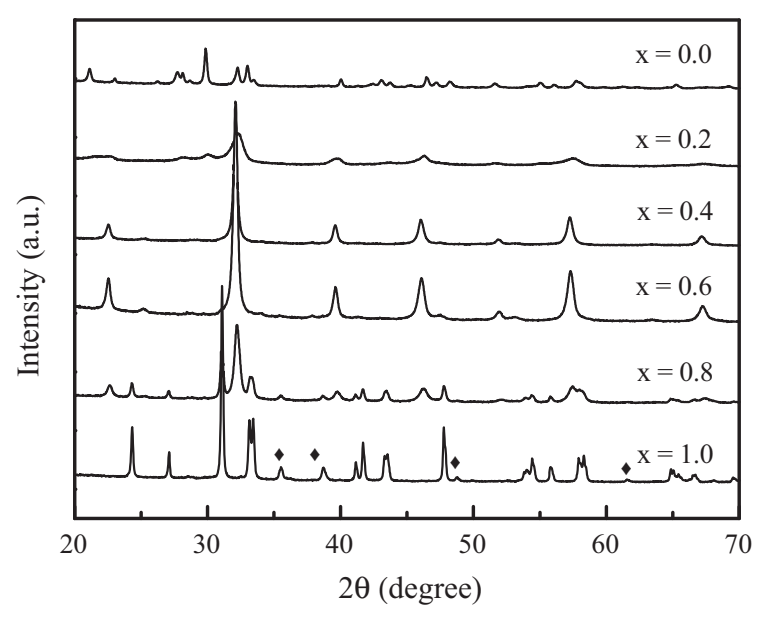

Fig. 1. XRD patterns of the $\mathrm{LaTi}_{1-x} \mathrm{Cu}_{x} \mathrm{O}_{3}$ powders.

The experiment data represented the average of the triplicates with a standard deviation less than $5 \%$.

\section{Results and discussion}

\subsection{Characterization of catalysts}

A series of $\mathrm{Cu}$-doped $\mathrm{LaTi}_{1-x} \mathrm{Cu}_{x} \mathrm{O}_{3}(x=0.0-1.0)$ was synthesized with a sol-gel method. Fig. 1 illustrated XRD patterns of the synthesized samples. All the characteristic peaks of the sample $X_{\mathrm{Cu}}=0$ were well assigned to $\mathrm{La}_{2} \mathrm{Ti}_{2} \mathrm{O}_{7}$ (JCPDS 81-1066). When $\mathrm{Cu}$ was introduced, the $\mathrm{La}_{2} \mathrm{Ti}_{2} \mathrm{O}_{7}$ phase disappeared and a $\mathrm{LaTiO}_{3}$ perovskite phase (JCPDS 75-0267) appeared. With an increase of $\mathrm{Cu}$ content from $X_{\mathrm{Cu}}=0.2$ to $X_{\mathrm{Cu}}=0.6$, the predominant peaks gradually became stronger and sharper, indicating an increase in the crystallinity of $\mathrm{LaTiO}_{3}$ phase. The addition of excessive $\mathrm{Cu}$ $\left(X_{\mathrm{Cu}}=0.8\right)$ in the preparation process resulted in the appearence of the impurities $\mathrm{La}_{2} \mathrm{CuO}_{4}$ (JCPDS 82-2142) and CuO (JCPDS 481548 ). In addition, the main phase of the sample $X_{\mathrm{Cu}}=1.0$ became $\mathrm{La}_{2} \mathrm{CuO}_{4}$ with a few $\mathrm{CuO}(\checkmark)$. It can be seen that a phase transition process occurred with an increase of Cu content. According to the XRD results, the introduction of $\mathrm{Cu}$ induced the formation of the crystalline phase $\mathrm{LaTiO}_{3}$ in which titanium existed as $\mathrm{Ti}^{3+}[21]$. The average size of $\mathrm{LaTi}_{0.4} \mathrm{Cu}_{0.6} \mathrm{O}_{3}$ crystallite was $38.2 \mathrm{~nm}$ based on the calculation with Scherer equation. The BET surface area was $8.5 \mathrm{~m}^{2} \mathrm{~g}^{-1}$.

In order to confirm the oxidation states of the surface metal species, XPS measurements were conducted on the samples $X_{\mathrm{Cu}}=0.0$ and $X_{\mathrm{Cu}}=0.6$. According to the XPS data, the La 3d peaks of both samples appeared at $834.1 \mathrm{eV}\left(3 \mathrm{~d}_{5 / 2}\right)$ and $850.7 \mathrm{eV}\left(3 \mathrm{~d}_{3 / 2}\right)$ which corresponded to $\mathrm{La}^{3+}$. As shown in Fig. 2, the strong peak at $458.0 \mathrm{eV}$ could be assigned to $\mathrm{Ti}^{4+}[22,23]$ for the sample $X_{\mathrm{Cu}}=0.0$, while the Ti $2 p_{3 / 2}$ peak of the sample $X_{\mathrm{Cu}}=0.6$ was well fit into the peaks of $\mathrm{Ti}^{3+}(\sim 457.5 \mathrm{eV})$ and $\mathrm{Ti}^{4+}(\sim 458.5 \mathrm{eV})[24]$ and the surface concentration ratio of $\mathrm{Ti}^{3+}$ to $\mathrm{Ti}^{4+}$ was about 4.6:1. Therefore, it was confirmed that the insertion of $\mathrm{Cu}$ into the $\mathrm{La} / \mathrm{Ti}$ system led to the conversion of the crystalline phase from $\mathrm{La}_{2} \mathrm{Ti}_{2} \mathrm{O}_{7}$ to $\mathrm{LaTiO}_{3}$, thus produced the existence environment of the $\mathrm{Ti}^{3+}$ ion which could exhibit higher Fenton catalytic activity. In the $\mathrm{Cu} 2 \mathrm{p}$ core level spectra of the sample $X_{\mathrm{Cu}}=0.6$, the peaks corresponding to $\mathrm{Cu} 2 \mathrm{p}_{3 / 2}$ were observed at ca. 932.6 and $934.2 \mathrm{eV}$ for reduced copper species and $\mathrm{Cu}^{2+}$, respectively [25]. $\mathrm{Cu}^{2+}$ ion could also be distinguished by the appearance of a shake-up satellite line at ca. 940.0-942.6 eV. The identification of the reduced copper species, i.e., $\mathrm{Cu}^{0}$ and/or $\mathrm{Cu}^{+}$, became extremely difficult by XPS data alone since the $\mathrm{BE}$ for $\mathrm{Cu}^{0}$ and $\mathrm{Cu}^{+}$were almost the same [26]. Therefore, AES measurements 


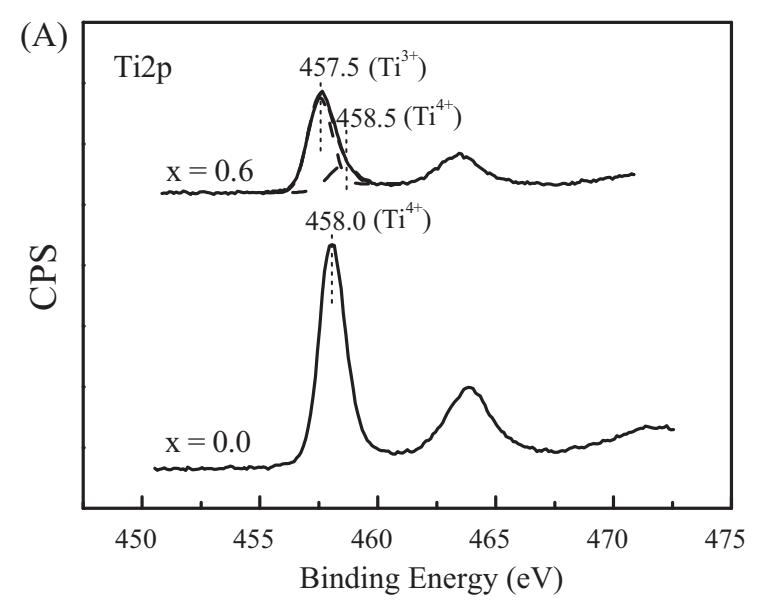

(B)
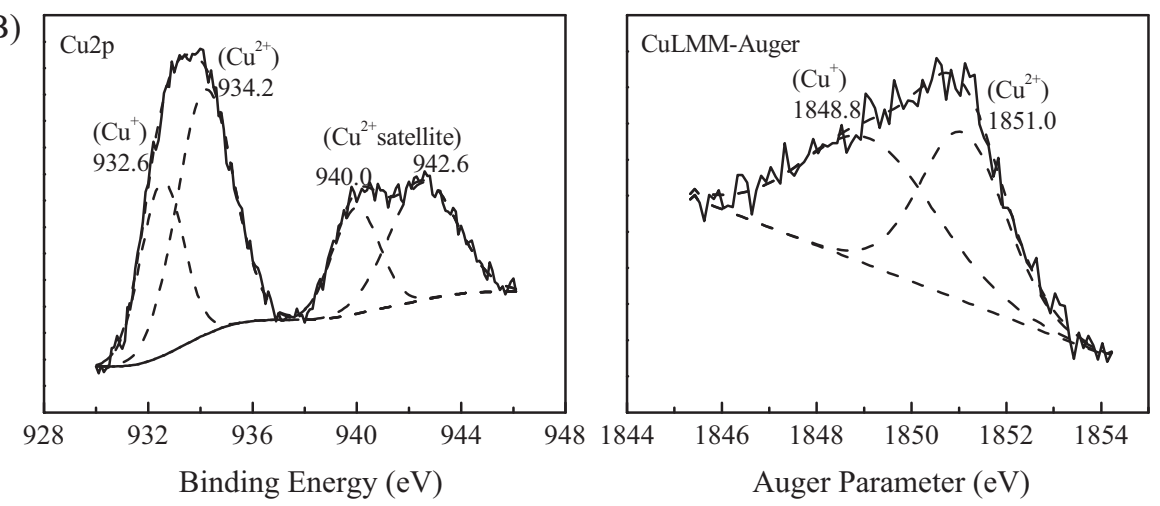

Fig. 2. XPS spectra of the $\mathrm{LaTi}_{1-x} \mathrm{Cu}_{x} \mathrm{O}_{3}$ powders: (A) Ti2p; (B) Cu2p (left) and LMM X-ray induced Auger parameter (right) for the sample $x=0.6$.

were performed. The auger parameters at $1848.8 \mathrm{eV}$ and $1851.0 \mathrm{eV}$ confirmed the existence of $\mathrm{Cu}^{+}$and $\mathrm{Cu}^{2+}$, respectively. The concentration ratio of $\mathrm{Cu}^{+}$to $\mathrm{Cu}^{2+}$ on the surface of the catalyst was about 0.28:1.

\subsection{Catalytic activity and stability of $\mathrm{LaTi}_{0.4} \mathrm{Cu}_{0.6} \mathrm{O}_{3}$}

The Fenton catalytic activity of $\mathrm{LaTi}_{1-x} \mathrm{Cu}_{x} \mathrm{O}_{3}$ was evaluated by the oxidation of $\mathrm{RhB}$ in aqueous solution with $\mathrm{H}_{2} \mathrm{O}_{2}$. As shown in Fig. 3, no significant decolorization was observed in the presence of the sample $X_{\mathrm{Cu}}=0\left(\mathrm{La}_{2} \mathrm{Ti}_{2} \mathrm{O}_{7}\right)$, while the introduction of

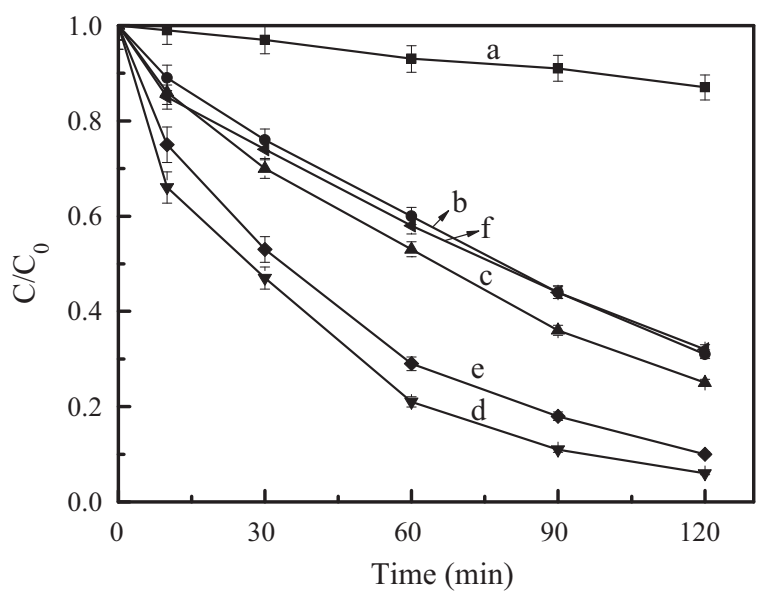

Fig. 3. Fenton-like degradation of $\mathrm{RhB}\left(8 \mathrm{mg} \mathrm{L}^{-1}\right)$ in the presence of $\mathrm{LaTi}_{1-x} \mathrm{Cu}_{x} \mathrm{O}_{3}$ suspensions ( $1.4 \mathrm{~g} \mathrm{~L}^{-1}$ ) and $\mathrm{H}_{2} \mathrm{O}_{2}(20 \mathrm{mM})$ : (a) $x=0.0$; (b) $x=0.2$; (c) $x=0.4$; (d) $x=0.6$; (e) $x=0.8$; and (f) $x=1.0$.

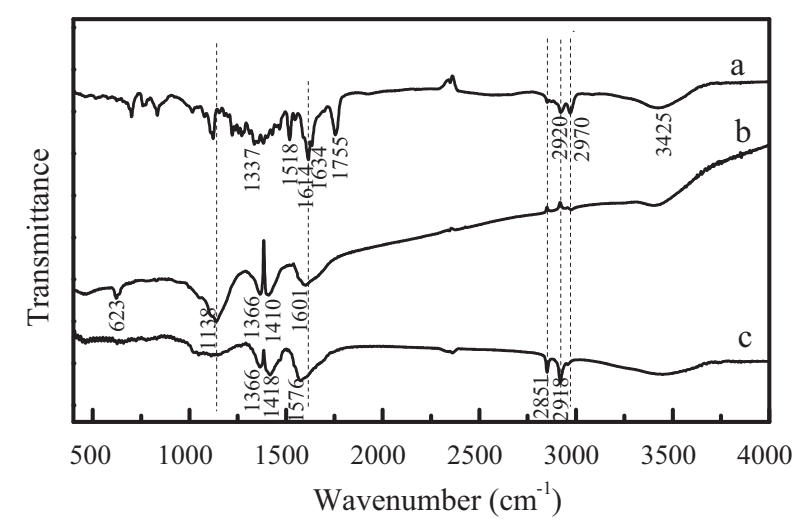

Fig. 4. Changes of FT-IR spectra during the degradation of $\mathrm{RhB}\left(8 \mathrm{mg} \mathrm{L}^{-1}\right)$ in $\mathrm{LaTi}_{0.4} \mathrm{Cu}_{0.6} \mathrm{O}_{3}\left(1.4 \mathrm{~g} \mathrm{~L}^{-1}\right)$ suspensions with $\mathrm{H}_{2} \mathrm{O}_{2}(20 \mathrm{mM})$ at different reaction times: (a) $0 \mathrm{~min}$; (b) $120 \mathrm{~min}$; and (c) $180 \mathrm{~min}$.

$\mathrm{Cu}$ strongly increased Fenton catalytic activity of the oxides. The decolorization rate of $\mathrm{RhB}$ increased with increasing $\mathrm{Cu}$ content in the catalysts from $X_{\mathrm{Cu}}=0.2$ to $X_{\mathrm{Cu}}=0.6$, but the presence of excessive $\mathrm{Cu}$ in the catalysts (i.e. $X_{\mathrm{Cu}}=0.8$ and 1.0) decreased the degradation of $\mathrm{RhB}$. Based on the obtained results, well-crystallized $\mathrm{LaTi}_{0.4} \mathrm{Cu}_{0.6} \mathrm{O}_{3}$ with a pure $\mathrm{LaTiO}_{3}$ phase had the highest activity. The results indicated that the coexistence of reduced metal ions $\mathrm{Ti}^{3+}$ and $\mathrm{Cu}^{+}$enhanced Fenton catalytic activity of the catalyst. In $\mathrm{LaTi}_{0.4} \mathrm{Cu}_{0.6} \mathrm{O}_{3} / \mathrm{H}_{2} \mathrm{O}_{2}$ suspension, about $94 \%$ of $\mathrm{RhB}$ was decolorized while about $57 \%$ of TOC content was removed within $120 \mathrm{~min}$ at neutral pH. The FT-IR spectra in Fig. 4 showed the degradation process of $\mathrm{RhB}$ in the presence of $\mathrm{LaTi}_{0.4} \mathrm{Cu}_{0.6} \mathrm{O}_{3}$ and $\mathrm{H}_{2} \mathrm{O}_{2}$. In curve $\mathrm{a}$, the band at $3425 \mathrm{~cm}^{-1}$ was due to $-\mathrm{OH}$ stretch vibration, and 
the bands at $2970,2920 \mathrm{~cm}^{-1}$ were caused by $-\mathrm{CH}_{2}-$ and $\mathrm{C}-\mathrm{CH}_{3}$ stretch vibrations, respectively $[27,28]$. The peaks at 1614,1547 , $1518,1466 \mathrm{~cm}^{-1}$ corresponded to aromatic ring vibrations, while the $1337 \mathrm{~cm}^{-1}$ peak attributed to $C$-aryl bond vibration; the peak at $1755 \mathrm{~cm}^{-1}$ was due to $\mathrm{C}=0$ groups. The peak at $1634 \mathrm{~cm}^{-1}$ was caused by the $\mathrm{C}-\mathrm{N}$ bond vibration and the heterocycle vibrations caused the peaks ranging at $1518-1547 \mathrm{~cm}^{-1}$. As shown in curve $\mathrm{b}$, the peak at $1614 \mathrm{~cm}^{-1}$ corresponded to aromatic ring vibrations shifted to $1601 \mathrm{~cm}^{-1}$ and other characteristic peaks disappeared after reaction for $120 \mathrm{~min}$. Meanwhile, the new peaks at 1410,1366, 1138 and $623 \mathrm{~cm}^{-1}$ appeared. The results indicated that the disappearance of the parental RhB structure and the generation of its primary aromatic breakdown products. In curve $c$, after reaction for $180 \mathrm{~min}$, the new strong peaks 1138 and $623 \mathrm{~cm}^{-1}$ disappeared, while 2918 and $2851 \mathrm{~cm}^{-1}$ for C-H asymmetric/symmetric stretching of $-\mathrm{CH}_{3}$ and $-\mathrm{CH}_{2}-$ groups appeared. Moreover, the new strong peak at $1030-1148 \mathrm{~cm}^{-1}$ was caused by $-\mathrm{C}-\mathrm{O}-\mathrm{H}$ stretch vibration. The results implied the intermediate organic products were further degraded into smaller organic molecules such as alcohols and inorganic species.

The stability and reusability of $\mathrm{LaTi}_{0.4} \mathrm{Cu}_{0.6} \mathrm{O}_{3}$ was evaluated by $\mathrm{RhB}$ degradation. The leaching of $\mathrm{La}$ and $\mathrm{Cu}$ from the catalyst $\mathrm{LaTi}_{0.4} \mathrm{Cu}_{0.6} \mathrm{O}_{3}$ during the $\mathrm{RhB}$ degradation process was tested by using ICP-OES method. It was found that there was no significant leaching of La and $\mathrm{Cu}$ ions at initial pH 9.0 and 6.8 in Fig. S1. At pH 4.0 , the concentrations of leached $\mathrm{La}$ and $\mathrm{Cu}$ were $4.6 \mathrm{mg} \mathrm{L}^{-1}$ and $1.4 \mathrm{mg} \mathrm{L}^{-1}$, respectively. In addition, no leaching of Ti was detected at the tested $\mathrm{pH}$. Especially, $\mathrm{LaTi}_{0.4} \mathrm{Cu}_{0.6} \mathrm{O}_{3}$ was able to be reused for at least six cycles and exhibited no significant loss of activity in Fig. 5. Furthermore, no significant difference was observed in the structure of $\mathrm{LaTi}_{0.4} \mathrm{Cu}_{0.6} \mathrm{O}_{3}$ between before and after reaction by XRD and XPS measurements as shown in Figs. 6 and 7. The results indicated that the catalyst had an excellent long-term stability.

\subsection{Effects of $\mathrm{H}_{2} \mathrm{O}_{2}$ concentration and initial $\mathrm{pH}$}

The effects of $\mathrm{H}_{2} \mathrm{O}_{2}$ concentration and initial pH on the catalytic activity of $\mathrm{LaTi}_{0.4} \mathrm{Cu}_{0.6} \mathrm{O}_{3}$ were investigated. As shown in Fig. 8, only $8 \%$ of $\mathrm{RhB}$ was decolorized without $\mathrm{H}_{2} \mathrm{O}_{2}$ even after reacting for $120 \mathrm{~min}$. The degradation of $\mathrm{RhB}$ was significantly accelerated in the presence of $\mathrm{H}_{2} \mathrm{O}_{2}$. When $10 \mathrm{mM} \mathrm{H}_{2} \mathrm{O}_{2}$ was added, about $84 \%$ of RhB was decolorized within $120 \mathrm{~min}$. And catalytic decolorization of up to $94 \%$ was observed with $20 \mathrm{mM} \mathrm{H}_{2} \mathrm{O}_{2}$ added. However, $\mathrm{H}_{2} \mathrm{O}_{2}$ dosage more than $20 \mathrm{mM}$ resulted in a slight increase in the decolorization due to an unprofitable consumption of $\mathrm{H}_{2} \mathrm{O}_{2}$ from the scavenging effect of $\mathrm{H}_{2} \mathrm{O}_{2}$. Fig. 9 shows the RhB degradation in $\mathrm{LaTi}_{0.4} \mathrm{Cu}_{0.6} \mathrm{O}_{3}$ with $20 \mathrm{mM} \mathrm{H}_{2} \mathrm{O}_{2}$ at different initial $\mathrm{pH}$.

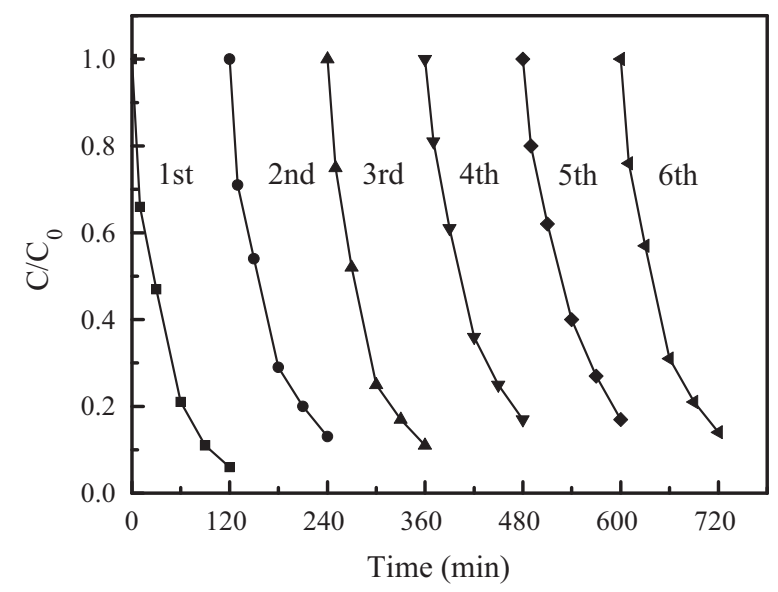

Fig. 5. Stability of the $\mathrm{LaTi}_{0.4} \mathrm{Cu}_{0.6} \mathrm{O}_{3}$ catalyst for the decolorization of $\mathrm{RhB}\left(8 \mathrm{mg} \mathrm{L}^{-1}\right)$.

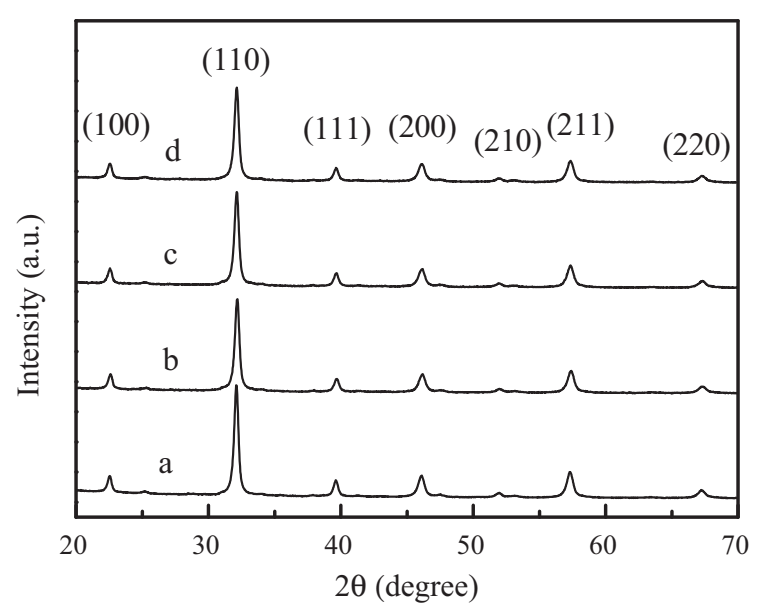

Fig. 6. XRD patterns of the $\mathrm{LaTi}_{0.4} \mathrm{Cu}_{0.6} \mathrm{O}_{3}$ powders: (a) as-prepared; (b) after the first run; (c) after the second run; and (d) after the third run.

$\mathrm{LaTi}_{0.4} \mathrm{Cu}_{0.6} \mathrm{O}_{3}$ exhibited a high catalytic activity at initial $\mathrm{pH}$ values from 4.0 to 6.8 , followed by a slight decrease of RhB decolorization at higher initial $\mathrm{pH}$ 9.0. As shown in the inset of Fig. 9, the solution $\mathrm{pH}$ gradually tended to be neutral during the adsorption of $\mathrm{RhB}$, then decreased slightly when $\mathrm{H}_{2} \mathrm{O}_{2}$ was added and finally stabilized during the catalytic reaction. It seemed that the catalyst LaTi ${ }_{0.4} \mathrm{Cu}_{0.6} \mathrm{O}_{3}$ had a good acid and alkaline buffer performance, which led to its excellent catalytic ability in a wide $\mathrm{pH}$ range.

\subsection{Reaction mechanism}

To ascertain the reaction mechanism, DMPO spin-trap ESR was performed to detect the reactive oxygen species (ROS) involved in the $\mathrm{LaTi}_{0.4} \mathrm{Cu}_{0.6} \mathrm{O}_{3} / \mathrm{H}_{2} \mathrm{O}_{2}$ system. As shown in Fig. 10, no significant signals were attributed to ROS in the control experiments in the absence of $\mathrm{H}_{2} \mathrm{O}_{2}$, while four characteristic peaks of DMPO- ${ }^{\bullet} \mathrm{OH}$ were observed in the suspension of $\mathrm{LaTi}_{0.4} \mathrm{Cu}_{0.6} \mathrm{O}_{3}$ with $\mathrm{H}_{2} \mathrm{O}_{2}$.

The formation of $\mathrm{HO}_{2} \bullet / \mathrm{O}_{2}{ }^{\bullet-}$ radicals was also detected in methanol (Fig. 10B), since the $\mathrm{HO}_{2} \bullet / \mathrm{O}_{2}{ }^{\bullet-}$ radicals in water were very unstable and underwent facile disproportionation rather than slow reaction with DMPO [29]. The sextet peaks of DMPO$\mathrm{HO}_{2} \bullet / \mathrm{O}_{2}{ }^{\bullet-}$ adducts were observed in $\mathrm{LaTi}_{0.4} \mathrm{Cu}_{0.6} \mathrm{O}_{3}$ suspension with $\mathrm{H}_{2} \mathrm{O}_{2}$. The results indicated $\mathrm{H}_{2} \mathrm{O}_{2}$ was decomposed into ${ }^{\circ} \mathrm{OH}$ and $\mathrm{HO}_{2} \bullet / \mathrm{O}_{2} \bullet-$ radicals by the redox reaction with $\mathrm{LaTi}_{0.4} \mathrm{Cu}_{0.6} \mathrm{O}_{3}$.

Furthermore, the effects of radical scavengers on the decolorization rate of $\mathrm{RhB}$ were investigated. $t$-Butanol and $p$-benzoquinone [30] were selected as $\bullet \mathrm{OH}$ and $\mathrm{HO}_{2} \bullet / \mathrm{O}_{2}{ }^{\bullet-}$ radical scavengers, respectively. The decolorization of $\mathrm{RhB}$ was almost completely depressed in the presence of $t$-butanol and only $25 \%$ of RhB was decolorized within $120 \mathrm{~min}$, while the addition of $p$-benzoquinone also inhibited the decolorization of RhB in Fig. 11. These results confirmed that both $\bullet \mathrm{OH}$ and $\mathrm{HO}_{2} \bullet / \mathrm{O}_{2}{ }^{\bullet-}$ radicals were the active species involved in the process of $\mathrm{RhB}$ degradation.

As shown in Fig. 12, the decomposition of $\mathrm{H}_{2} \mathrm{O}_{2}(20 \mathrm{mM})$ was still incomplete after $20 \mathrm{~h}$ reaction in $\mathrm{LaTi}_{0.4} \mathrm{Cu}_{0.6} \mathrm{O}_{3}$ without organic compounds, and the presence of the substrate RhB decreased the decomposition of $\mathrm{H}_{2} \mathrm{O}_{2}$. These results suggested that the $\mathrm{H}_{2} \mathrm{O}_{2}$ decomposition and the $\mathrm{RhB}$ oxidation were competitive processes involving the same active species [31], which reacted with $\mathrm{H}_{2} \mathrm{O}_{2}$ enhancing the decomposition rate, indicating that $\mathrm{H}_{2} \mathrm{O}_{2}$ was predominantly decomposed into active radicals rather than $\mathrm{O}_{2}$.

The oxygen vacancy played a fundamental role in reducing $\mathrm{H}_{2} \mathrm{O}_{2}$ to $\mathrm{O}_{2}$ [32]. Moreover, there was a considerable amount of oxygen vacancy on the surface of $\mathrm{LaTi}_{0.4} \mathrm{Cu}_{0.6} \mathrm{O}_{3}$ (Fig. S2 and Table S1), which was calculated from the variation of area ratio of the two $\mathrm{O} 1 \mathrm{~s}$ peaks according to the reported method [33]. However, the $\mathrm{H}_{2} \mathrm{O}_{2}$ 

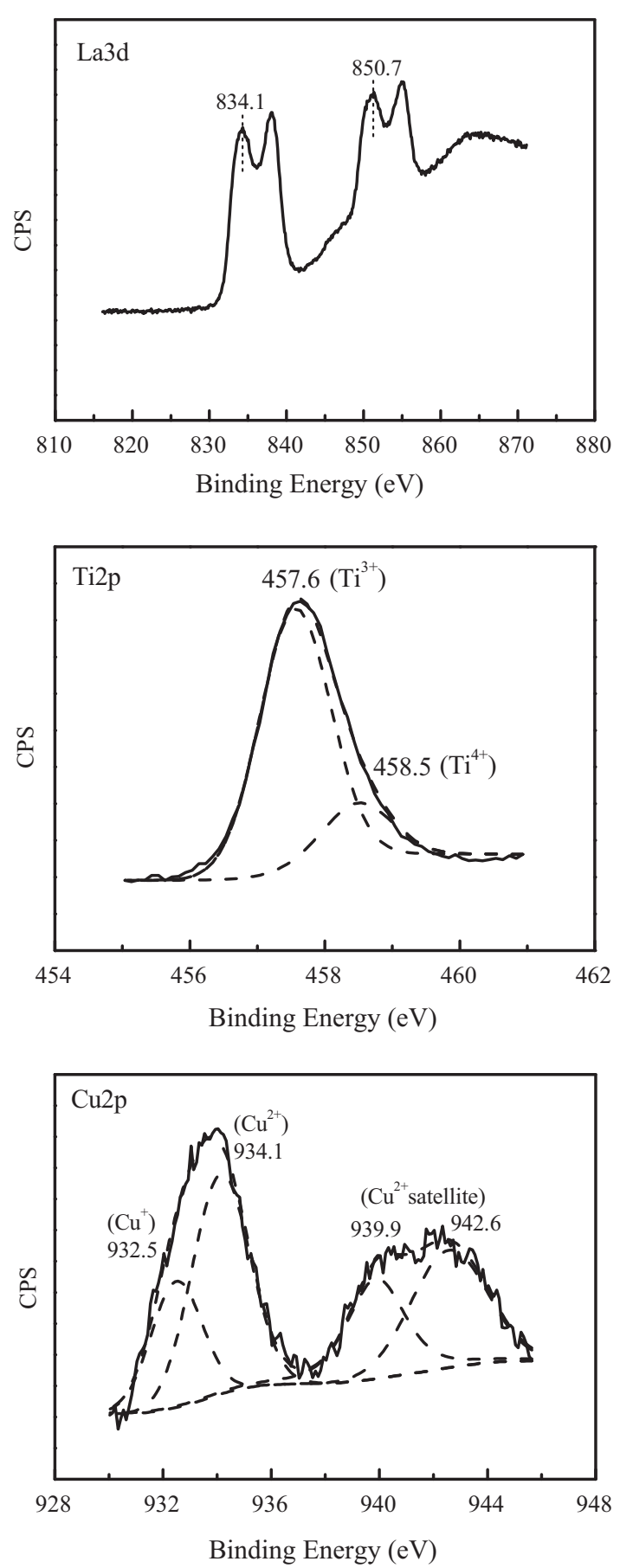

Fig. 7. XPS spectra of the $\mathrm{LaTi}_{0.4} \mathrm{Cu}_{0.6} \mathrm{O}_{3}$ powders after reaction.

decomposition reaction proceeded via a radical mechanism by the studies of electron spin resonance, the effect of radical scavengers and the $\mathrm{H}_{2} \mathrm{O}_{2}$ decompositon experiments, indicating that the oxygen vacancy did not influence much on the reaction due to the role of $\mathrm{Cu}$ and $\mathrm{Ti}$ in the catalyst.

The presence of $\mathrm{Ti}^{3+/ 4+}$ and $\mathrm{Cu}^{+/ 2+}$ on the surface of $\mathrm{LaTi}_{0.4} \mathrm{Cu}_{0.6} \mathrm{O}_{3}$ was confirmed using the XPS technology. The surface concentration ratio of $\mathrm{Ti}^{3+}$ to $\mathrm{Ti}^{4+}$ was about $4.6: 1$ and that of $\mathrm{Cu}^{+}$to $\mathrm{Cu}^{2+}$ was about $0.28: 1$ before reaction, while the surface concentration ratio of $\mathrm{Ti}^{3+}$ to $\mathrm{Ti}^{4+}$ was about $5.1: 1$ and that of $\mathrm{Cu}^{+}$ to $\mathrm{Cu}^{2+}$ was about $0.23: 1$ after reaction. There was no significant difference in $\mathrm{Ti}^{3+} / \mathrm{Ti}^{4+}$ or $\mathrm{Cu}^{+} / \mathrm{Cu}^{2+}$ on the surface of catalyst before and after catalytic reaction, suggesting $\mathrm{Cu}^{+}\left(\mathrm{Ti}^{3+}\right)$ participated in the

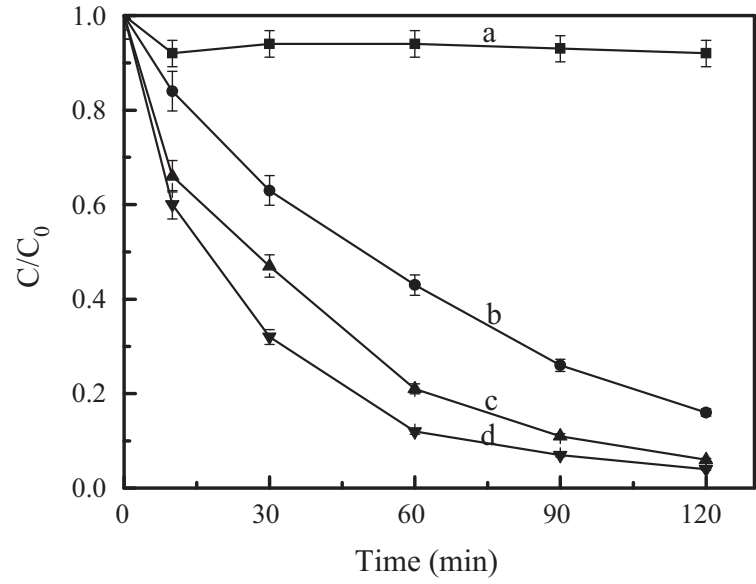

Fig. 8. Effect of initial concentration of $\mathrm{H}_{2} \mathrm{O}_{2}$ on decolorization of $\mathrm{RhB}\left(8 \mathrm{mg} \mathrm{L}^{-1}\right)$ in $\mathrm{LaTi}_{0.4} \mathrm{Cu}_{0.6} \mathrm{O}_{3}\left(1.4 \mathrm{~g} \mathrm{~L}^{-1}\right)$ suspensions: (a) $0 \mathrm{mM}$; (b) $10 \mathrm{mM}$; (c) $20 \mathrm{mM}$; and (d) $40 \mathrm{mM}$.

redox cycle. In addition, ESR and the radical inhibition experiments had confirmed $\bullet \mathrm{OH}$ and $\mathrm{HO}_{2} \bullet / \mathrm{O}_{2}{ }^{\bullet-}$ radicals were the active species. These results suggested that an interfacial electron cycle process occurred (Eqs. (1)-(6)) according to the experimental data and a review of the literature [34-37]. A mechanism for ROS formation was proposed as follows:

$$
\begin{aligned}
& \mathrm{Ti}^{3+}+\mathrm{H}_{2} \mathrm{O}_{2} \rightarrow \mathrm{Ti}^{4+}+\bullet \mathrm{OH}+\mathrm{OH}^{-} \\
& \mathrm{Cu}^{2+}+\mathrm{H}_{2} \mathrm{O}_{2} \rightarrow \mathrm{Cu}^{+} \cdot \mathrm{O}_{2} \mathrm{H}+\mathrm{H}^{+} \\
& \mathrm{Cu}^{+} \cdot \mathrm{O}_{2} \mathrm{H}+\mathrm{H}_{2} \mathrm{O}_{2} \rightarrow \mathrm{Cu}^{+}+\mathrm{O}_{2}+\bullet \mathrm{OH}+\mathrm{H}_{2} \mathrm{O} \\
& \mathrm{H}^{+}+\mathrm{Cu}^{+}+\mathrm{H}_{2} \mathrm{O}_{2} \rightarrow \mathrm{Cu}^{2+}+\cdot \mathrm{OH}+\mathrm{H}_{2} \mathrm{O} \\
& \mathrm{H}_{2} \mathrm{O}_{2}+\cdot \mathrm{OH} \rightarrow \mathrm{H}_{2} \mathrm{O}+\mathrm{HO}_{2} \\
& \mathrm{Ti}^{4+}+\mathrm{HO}_{2} \cdot \mathrm{Ti}^{3+}+\mathrm{H}^{+}+\mathrm{O}_{2} \\
& \mathrm{RhB}_{+} \cdot \mathrm{OH} \rightarrow \ldots \rightarrow \mathrm{CO}_{2}+\mathrm{H}_{2} \mathrm{O}
\end{aligned}
$$

$\mathrm{Ti}^{3+}$, as the main surface $\mathrm{Ti}$ species, initiated redox cycling to generate $\mathrm{OH}$ radicals via the Harber-Weiss reaction (Eq. (1)). $\mathrm{Cu}^{2+}$ catalyzed the decomposition of $\mathrm{H}_{2} \mathrm{O}_{2}$ into $\mathrm{OH}$ radicals as Eqs. (2)-(4). $\mathrm{Cu}^{+}$was also Fenton active and could participate in radicalgenerating cycles. The active species might react with $\mathrm{H}_{2} \mathrm{O}_{2}$ and $\mathrm{Ti}^{4+}$ to form $\mathrm{O}_{2}$ (Eqs. (5) and (6)) or oxidize the organic molecule in aqueous medium (Eq. (7)). The more content of $\mathrm{Ti}^{4+}$ in the catalyst was not useful for the degradation of $\mathrm{RhB}$ in the Fenton reaction.

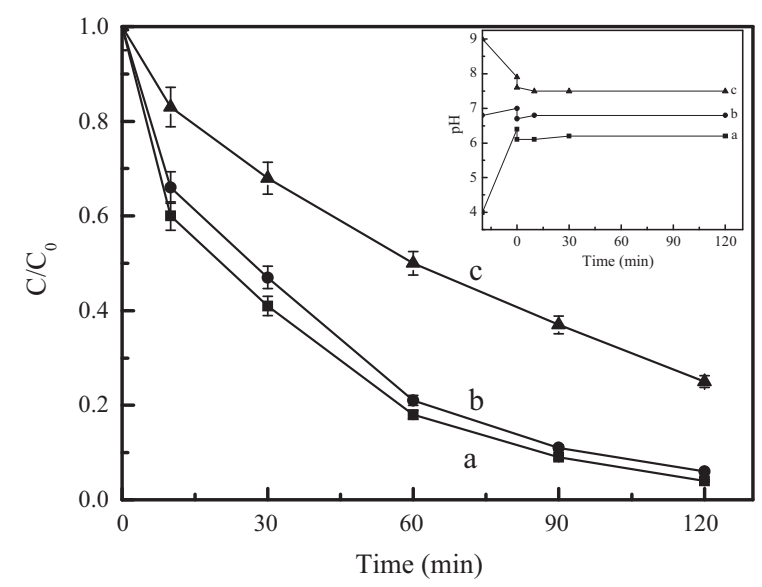

Fig. 9. Effect of initial $\mathrm{pH}$ on decolorization of $\mathrm{RhB}\left(8 \mathrm{mg} \mathrm{L}^{-1}\right)$ in the presence of LaTi ${ }_{0.4} \mathrm{Cu}_{0.6} \mathrm{O}_{3}$ suspensions (1.4 $\mathrm{g} \mathrm{L}^{-1}$ ) and $\mathrm{H}_{2} \mathrm{O}_{2}$ (20 mM): (a) 4.0; (b) 6.8; and (c) 9.0. The inset indicates the changes of solution $\mathrm{pH}$ during reaction. 

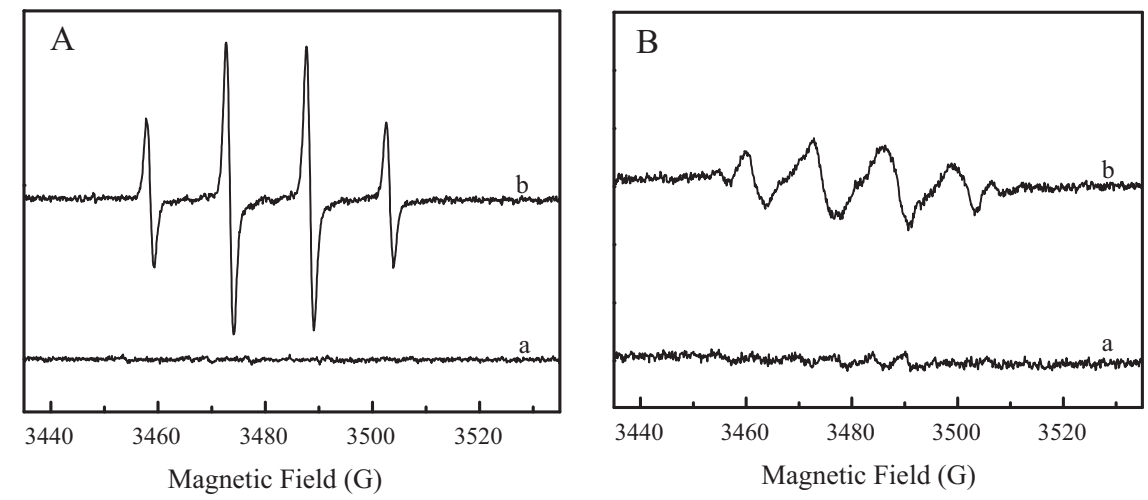

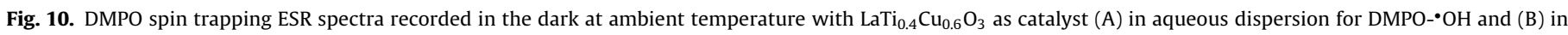
methanol dispersion for DMPO- $\mathrm{HO}_{2} \cdot / \mathrm{O}_{2} \cdot-$ : (a) without and (b) with $\mathrm{H}_{2} \mathrm{O}_{2}$.

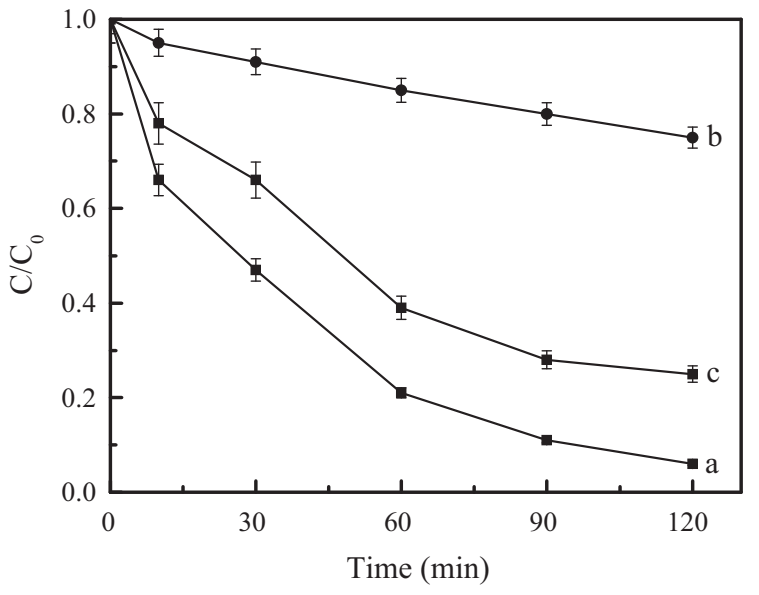

Fig. 11. Decolorization of $\mathrm{RhB}\left(8 \mathrm{mg} \mathrm{L}^{-1}\right)$ in the presence of $\mathrm{LaTi}_{0.4} \mathrm{Cu}_{0.6} \mathrm{O}_{3}$ suspensions ( $1.4 \mathrm{~g} \mathrm{~L}^{-1}$ ) and $\mathrm{H}_{2} \mathrm{O}_{2}(20 \mathrm{mM}$ ) with (a) no scavenger added,(b) $10 \mathrm{mM} t$-butanol, and (c) $10 \mathrm{mM}$ p-benzoquinone.

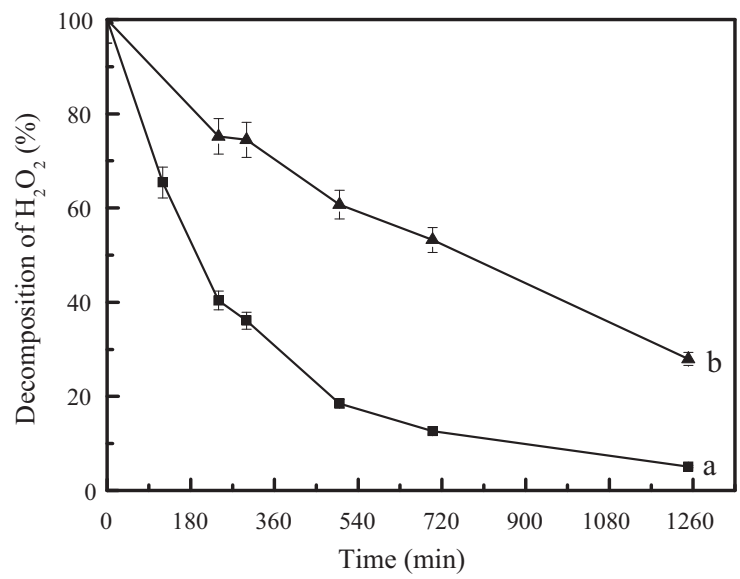

Fig. 12. Decomposition of $\mathrm{H}_{2} \mathrm{O}_{2}$ in the systems of (a) $\mathrm{LaTi}_{0.4} \mathrm{Cu}_{0.6} \mathrm{O}_{3}\left(1.4 \mathrm{~g} \mathrm{~L}^{-1}\right)-\mathrm{H}_{2} \mathrm{O}_{2}$ $(20 \mathrm{mM})-\mathrm{H}_{2} \mathrm{O}$ and (b) $\mathrm{LaTi}_{0.4} \mathrm{Cu}_{0.6} \mathrm{O}_{3}\left(1.4 \mathrm{~g} \mathrm{~L}^{-1}\right)-\mathrm{H}_{2} \mathrm{O}_{2}(20 \mathrm{mM})-\mathrm{RhB}\left(8 \mathrm{mg} \mathrm{L}^{-1}\right)$.

It was also in line with the existence of an optimum value for the $\mathrm{H}_{2} \mathrm{O}_{2}$ concentration due to the radical scavenging effect of $\mathrm{H}_{2} \mathrm{O}_{2}$.

\section{Conclusions}

Nanoscaled $\mathrm{Cu}$-doped $\mathrm{LaTiO}_{3}$ perovskite exhibited high activity and stability for the decolorization and mineralization of RhB with $\mathrm{H}_{2} \mathrm{O}_{2}$ in the initial $\mathrm{pH}$ range of $4-9$. ${ }^{\bullet} \mathrm{OH}$ and $\mathrm{HO}_{2} \bullet / \mathrm{O}_{2}{ }^{\bullet-}$ radicals were the main active species in the reaction by the studies of ESR and the radical inhibition effect. The insertion of $\mathrm{Cu}$ into the $\mathrm{La} / \mathrm{Ti}$ system led to the conversion of the crystalline phase from $\mathrm{La}_{2} \mathrm{Ti}_{2} \mathrm{O}_{7}$ to $\mathrm{LaTiO}_{3}$, thus resulting in the existence of $\mathrm{Ti}^{3+}$ as the predominant titanium species in the perovskite structure which could exhibit high Fenton catalytic activity. $\mathrm{Cu}^{2+}$ could initiate redox cycling to generate active radicals and $\mathrm{Cu}^{+}$was also Fenton active to participate in radical-generating cycles. As a whole, the coexistence of $\mathrm{Ti}^{3+/ 4+}$ and $\mathrm{Cu}^{+/ 2+}$ in the perovskite structure greatly enhanced the $\mathrm{H}_{2} \mathrm{O}_{2}$ decomposition into active radicals, resulting in the high Fenton catalytic activity.

\section{Acknowledgments}

This work was supported by the National Natural Science Foundation of China (nos. 50908223, 50921064, and 21125731) and the National 973 Project of China (grant no. 2010CB933600).

\section{Appendix A. Supplementary data}

Supplementary data associated with this article can be found, in the online version, at http://dx.doi.org/10.1016/ j.apcatb.2012.06.015.

\section{References}

[1] F. Haber, J. Weiss, R. Proc, Proceedings of the Royal Society of London Series A 147 (1934) 332-351.

[2] D.L. Sedlak, A.W. Andren, Environmental Science and Technology 25 (1991) 777-782.

[3] J.J. Pignatello, Environmental Science and Technology 26 (1992) 944-951.

[4] S. Parra, I. Guasaquillo, O. Enea, E. Mielczarski, J. Mielczarki, P. Albers, L. KiwiMinsker, J. Kiwi, Journal of Physical Chemistry B 107 (2003) 7026-7035.

[5] R.C.C. Costa, M.F.F. Lelis, L.C.A. Oliveira, J.D. Fabris, J.D. Ardisson, R.R.V.A. Rios, C.N. Silva, R.M. Lago, Journal of Hazardous Materials 129 (2006) 171-178.

[6] F. Magalhães, M.C. Pereira, S.E.C. Botrel, J.D. Fabris, W.A. Macedo, R. Mendonça, R.M. Lago, L.C.A. Oliveira, Applied Catalysis A: General 332 (2007) 115-123.

[7] A.C. Silva, D.Q.L. Oliveira, L.C.A. Oliveira, A.S. Anastácio, T.C. Ramalho, J.H. Lopes, H.W.P. Carvalho, C.E.R. Torres, Applied Catalysis A: General 357 (2009) 79-84.

[8] S. Yang, H. He, D. Wu, D. Chen, X. Liang, Z. Qin, M. Fan, J. Zhu, P. Yuan, Applied Catalysis B: Environmental 89 (2009) 527-535.

[9] M.B. Kasiri, H. Aleboyeh, A. Aleboyeh, Applied Catalysis B: Environmental 84 (2008) 9-15.

[10] B. Iurascu, I. Siminiceanu, D. Vione, M.A. Vicente, A. Gil, Water Research 43 (2009) 1313-1322.

[11] G.K. Zhang, Y.Y. Gao, Y.L. Zhang, Y.D. Guo, Environmental Science and Technology 44 (2010) 6384-6389.

[12] F. Duarte, F.J. Maldonado-Hódar, A.F. Pérez-Cadenas, L.M. Madeira, Applied Catalysis B: Environmental 85 (2009) 139-147.

[13] L.L. Zhang, Y.L. Nie, C. Hu, X.X. Hu, Journal of Hazardous Materials 190 (2011) 780-785.

[14] W. Luo, L.H. Zhu, N. Wang, H.Q. Tang, M.J. Cao, Y.B. She, Environmental Science and Technology 44 (2010) 1786-1791.

[15] M.K. Eberhardt, G. Ramirez, E. Ayala, Journal of Organic Chemistry 54 (1989) 5922-5926. 
[16] G. Lassmann, L.A. Eriksson, F. Himo, F. Lendzian, W. Lubitz, Journal of Physical Chemistry A 103 (1999) 1283-1290.

[17] R.J.H. Voorhoeve, D.W. Johnson, J.P. Remeika, P.K. Gallagher, Science 195 (1977) 827-833.

[18] J.J. Zhu, A. Thomas, Applied Catalysis B: Environmental 92 (2009) 225-233.

[19] F.J. Beltran, P. Pocostales, P.M. Alvarez, F. Lopez-Pineiro, Applied Catalysis B: Environmental 92 (2009) 262-270.

[20] H. Bader, V. Sturzenegger, J. Hoigne, Water Research 22 (1988) 1109-1115.

[21] A.A. Mozhegorov, A.E. Nikiforov, A.V. Larin, A.V. Efremov, L.E. Gonchar, P.A. Agzamova, Physics of the Solid State 50 (2008) 1795-1798.

[22] Y.A. Teterin, S.V. Stefanovskij, S.V. Yudintsev, G.N. Bek-uzarov, A.Y. Teterin, K.I. Maslakov, I.O. Utkin, Nuclear Technology \& Radiation Protection 19 (2004) 31-38.

[23] Y. Masuda, R. Mashima, M. Yamada, K. Ikeuchi, K. Murai, G.I.N. Waterhouse, J.B. Metson, T. Moriga, Journal of the Ceramic Society of Japan 117 (2009) 76-81.

[24] S. Song, J.J. Tu, Z.Q. He, F.Y. Hong, W.P. Liu, J.M. Chen, Applied Catalysis A: General 378 (2010) 169-174.

[25] F.E. Lopez-Suarez, S. Parres-Esclapez, A. Bueno-Lopez, M.J. Illan-Gomez, B. Ura, J. Trawczynski, Applied Catalysis B: Environmental 93 (2009) 82-89.

[26] J.L.G. Fierro, Catalysis Reviews 34 (1992) 321-336.
[27] G. Liu, X. Li, J. Zhao, H. Hidaka, N. Serpone, Environmental Science and Technology 34 (2000) 3982-3990.

[28] J.Y. Li, W.H. Ma, P.X. Lei, J.C. Zhao, Journal of Environmental Science 19 (2007) 892-896.

[29] W.H. Ma, Y.P. Huang, J. Li, M.M. Cheng, W.J. Song, J.C. Zhao, Chemical Communications (2003) 1582-1583.

[30] M.C. Yin, Z.S. Li, J.H. Kou, Z.G. Zou, Environmental Science and Technology 43 (2009) 8361-8366.

[31] R.C.C. Costa, M.d.F.F. Lelis, L.C.A. Oliveira, J.D. Fabris, J.D. Ardisson, R.R.V.A. Rios, C.N. Silva, R.M. Lago, Catalysis Communications 4 (2003) 525-529.

[32] Y.N. Lee, R.M. Lago, J.L.G. Fierro, J. González, Applied Catalysis A: General 215 (2001) 245-256.

[33] W. Cao, O.K. Tan, J.S. Pan, W. Zhua, C.V.G. Reddy, Materials Chemistry and Physics 75 (2002) 67-70.

[34] Y. Ohashi, H. Yoshioka, H. Yoshioka, Bioscience, Biotechnology, and Biochemistry 66 (2002) 847-852.

[35] C. Randorn, S. Wongnawa, P. Boonsin, ScienceAsia 30 (2004) 149-156.

[36] C. Wang, L. Liu, L. Zhang, Y. Peng, F. Zhou, Biochemistry 49 (2010) 8134-8142.

[37] L. Khachatryan, E. Vejerano, S. Lomnicki, B. Dellinger, Environmental Science and Technology 45 (2011) 8559-8566. 